\title{
Pengaruh Rimpang Kunyit (Curcuma domestica, Val.) terhadap Bakteri Usus secara in vitro
}

The Effect of Turmeric Rhizome (Curcuma domestica, Val.) on Intestinal Bacteria in vitro

\author{
Didiek Hardiyanto Soegiantoro ${ }^{1 *}$, Gregory Hope Soegiantoro², Intan Selvyanti Waruwu1, Yanti \\ Octavia Theressia ${ }^{1}$ \\ ${ }^{1}$ Fakultas Farmasi, Universitas Kristen Immanuel, Yogyakarta \\ 2 SMA Negeri 3, Yogyakarta \\ Received: 2/1/2021 Accepted: 11/2/2021 Published: 30/3/2021 \\ *Korespondensi: didiek@ukrimuniversity.ac.id
}

\begin{abstract}
The use of turmeric rhizome to treat diarrhea is written in the original Indonesian medicinal manuscript. Diarrhea disease is still a public health problem in Indonesia, because of its high morbidity and mortality. One of the causes of diarrhea is an uncontrolled increase in the number of intestinal bacteria and infection by intestinal pathogenic bacteria. This study aims to determine the effect of the turmeric rhizome preparation process, both traditionally and by extraction method by maceration and soxhletation on antibacterial activity, especially intestinal bacteria, so that it can be applied by the traditional medicine industry as well as traditional herbal medicine sellers ("jamu gendong"). The research method used was to test the antibacterial activity of fresh turmeric juice, pre-dried turmeric juice, turmeric extract by maceration using $95 \%$ ethanol, and turmeric extract by soxhletation at $100^{\circ} \mathrm{C}$ using $95 \%$ ethanol. The intestinal bacteria used in this study were Escherichia coli, Yersinia enterolitica, Vibrio nonagglutinable, and Shigella flexneri. The results of this study indicate that the treatment process using the traditional method, both fresh turmeric juice and pre-dried turmeric juice, does not show any antibacterial activity. Turmeric extract by maceration showed antibacterial activity against all bacterias and the greatest against Vibrio nonagglutinable bacteria. Turmeric extract by soxhletation showed antibacterial activity against all bacterias and the greatest against Vibrio nonagglutinable bacteria. The conclusion of this study is that the most appropriate method used to process turmeric rhizome as a medicine for diarrhea caused by bacteria is the extraction method by maceration or soxhletation. The greatest antibacterial effect is against the Vibrio nonagglutinable bacteria.
\end{abstract}

Keywords: turmeric, herbal medicine, antibacterial, diarrhea, Vibrio

\begin{abstract}
Abstrak
Penggunaan rimpang kunyit untuk mengobati diare tertulis dalam manuskrip obat asli Indonesia. Salah satu penyebab diare adalah peningkatan jumlah bakteri usus yang tidak terkendali dan infeksi oleh bakteri patogen usus. Penelitian ini bertujuan untuk mengetahui pengaruh proses preparasi bahan rimpang kunyit secara tradisional maupun metode ekstraksi maserasi dan soxhletasi terhadap daya antibakteri khususnya bakteri usus sehingga dapat diterapkan oleh industri obat tradisional maupun penjual jamu tradisional. Metode yang digunakan adalah menguji daya antibakteri perasan kunyit segar, perasan kunyit yang sudah dikeringkan, ekstrak kunyit dengan metode maserasi etanol 95\%, dan ekstrak kunyit dengan metode soxhletasi pada suhu $100^{\circ} \mathrm{C}$ menggunakan etanol $95 \%$. Bakteri usus yang digunakan adalah Escherichia coli, Yersinia enterolitica, Vibrio nonaglutinable, dan Shigella flexneri. Hasil penelitian menunjukkan proses perlakuan dengan cara tradisional, yaitu perasan kunyit segar dan perasan kunyit yang sudah dikeringkan sebelumnya tidak menunjukkan efek antibakteri. Ekstrak kunyit dengan cara maserasi menunjukkan daya antibakteri terhadap semua bakteri uji dan terbesar terhadap bakteri Vibrio nonaglutinable. Ekstrak kunyit dengan cara soxhletasi menunjukkan daya antibakteri terhadap semua bakteri uji dan terbesar terhadap bakteri Vibrio nonaglutinable. Kesimpulan penelitian ini adalah metode yang paling tepat digunakan untuk memproses rimpang kunyit sebagai obat diare yang diakibatkan oleh bakteri adalah dengan metode ekstraksi dengan cara maserasi atau ekstraksi dengan cara soxhletasi. Efek antibakteri terbesar adalah terhadap bakteri Vibrio nonaglutinable.
\end{abstract}

Kata kunci: kunyit, jamu, antibakteri, diare, Vibrio. 


\section{PENDAHULUAN}

Penggunaan obat tradisional di Indonesia sudah berlangsung sejak ribuan tahun yang lalu, sebelum obat modern ditemukan dan dipasarkan. Penggunaan obat tradisional akhir-akhir ini semakin meningkat sejalan dengan program pemerintah untuk mengembangkan obat alam Indonesia. Definisi obat tradisional ialah bahan atau ramuan bahan yang berasal dari tumbuhan, hewan, mineral, sediaan sarian (galenik) atau campuran dari bahan tersebut, yang secara turun temurun telah digunakan untuk pengobatan berdasarkan pengalaman (Dewoto, 2007). Potensi perkembangan industri farmasi dengan memanfaatkan tumbuhan obat tradisional sangat tinggi di Indonesia. Hal ini terjadi salah satunya karena perubahan pola hidup manusia untuk mulai mengkonsumsi obat-obatan dari bahan alami dan mengurangi konsumsi obat-obatan kimiawi, sesuai dengan konsep kembali ke alam (back to nature). Penyebab lain adalah mahalnya obat-obatan kimiawi modern sehingga pilihan alternatif obat herbal dengan bahan alami menjadi pilihan (Nugroho, 2017).

Diare adalah buang air besar sebanyak tiga kali atau lebih dengan konsistensi lembek atau cair yang terjadi dalam satu hari serta frekuensi lebih sering daripada orang normal (Permatasari dan Hartanti, 2011). Diare termasuk dalam sepuluh besar penyakit yang dilaporkan masyarakat. Hal ini menunjukkan penyakit ini tetap ada di masyarakat dengan kejadian yang hampir sama tiap tahunnya. Kematian akibat diare umumnya disebabkan oleh mencret yang terjadi tak berkesudahan sehingga penderita kehilangan cairan dan elektrolit dalam tubuh yang menyebabkan dehidrasi. Salah satu penyebab diare adalah adanya bakteri patogen penyebab diare atau kelebihan jumlah bakteri normal usus (Irianto, 2000).

Rimpang kunyit (Curcuma domestica, Val.) digunakan untuk mengobati diare. Penggunaan rimpang kunyit dalam jamu sebagai obat diare telah digunakan secara turun-temurun. Cara penggunaan rimpang kunyit sebagai obat diare secara tradisional yang diturunkan turun-temurun adalah menggunakan perasan dari rimpang kunyit segar yang diberi sedikit garam atau menggunakan irisan rimpang kunyit kering yang digiling halus lalu diberi air dan disaring (Permatasari dan Hartanti, 2011).

Kunyit (Curcuma domestica Val) megandung senyawa alkaloid, flavonoid, kurkumin, minyak atsiri, saponin, tanin dan terpenoid. Kurkumin dan minyak atsiri terbukti memiliki kemampuan sebagai antiinflamasi. Senyawa kurkuminoid memiliki khasiat sebagai antibakteri, antikejang, analgetik, antidiare, antipiretik dan antitumor. Senyawa kurkumin termasuk ke dalam hasil metabolit sekunder dari tanaman (Muadifah et.al., 2019).

Penelitian ini bertujuan untuk mengetahui daya antibakteri rimpang kunyit dari proses pengolahan jamu secara tradisional dan dengan ekstraksi dalam pelarut organik. Penelitian ini bertujuan untuk membuktikan apakah cara tradisional yang digunakan turun-temurun memiliki daya antbakteri kemudian dibandingkan dengan cara ekstraksi.

Selain itu penelitian ini juga bertujuan mengetahui jenis bakteri yang paling sensitif terhadap terhadap rimpang kunyit.

\section{BAHAN DAN METODE Bahan}

Bahan rimpang kunyit (Curcuma domestica, Val.) diambil dari petani di daerah Wates, Kulonprogo, Daerah Istimewa Yogyakarta. Bahan kimia yang digunakan dalam proses penyarian dan uji daya antibakteri jika tidak disebutkan lain berarti menggunakan bahan pelarut dan bahan kimia berderajat murni pro analysis buatan E. Merck. Bahan kimia yang digunakan dalam penelitian ini adalah etanol, aquabidest, dan amilum. 
Alat

Berbagai alat digunakan dalam penelitian termasuk alat gelas yang biasa digunakan di laboratorium, selain itu digunakan allihn condenser dengan labu $500 \mathrm{ml}$ buatan Pyrex, heating mantle $500 \mathrm{ml}$, kipas angin Maspion EF-302, rotary evaporator IKA RV-10, blender Phillips HR2115 , kotak aseptis, osa platina $0,001 \mathrm{ml}$, inkubator Memmert IN-55, transfer pipet Socorex Swiss, mikropipet Eppendorf 100$1000 \mu \mathrm{L}$.

\section{Metode}

Tahap pertama dilakukan determinasi tanaman rimpang kunyit untuk memastikan bahwa simplisia yang dipakai sesuai dengan jenis dan spesiesnya (Muadifah et.al., 2019).

Tahap kedua adalah preparasi bahan rimpang kunyit dari empat jenis metode yang menjadi variabel bebas. Perlakuan 1 dan 2 disesuaikan dengan cara pembuatan jamu dari resep turun-temurun nenek moyang (Permatasari dan Hartanti, 2011). Sedangkan perlakuan 3 dan 4 menggunakan teknik ekstraksi bahan alam, yaitu dengan cara maserasi dan soxhletasi panas menggunakan pelarut etanol 95\%. Pemilihan cara soxhletasi dan maserasi didasarkan pada perbedaan suhu, dimana maserasi dilakukan pada suhu ruang, sedangkan soxhletasi dilakukan pada suhu $100^{\circ} \mathrm{C}$. Selain itu pergantian pelarut pada proses soxhletasi dianggap lebih efektif dalam ekstraksi karena pelarut yang dialirkan tidak pernah jenuh.

Rimpang kunyit untuk perlakuan 1, yaitu perasan rimpang segar, digunakan 100 gram rimpang segar, dicuci bersih, lalu diblender dan diperas. Hasil perasan diuapkan dengan menggunakan kipas angin sampai tinggal 50 $\mathrm{ml}$.

Rimpang kunyit untuk perlakuan 2, yaitu perasan rimpang kering, dilakukan dengan cara rimpang kunyit segar diiris tipis-tipis dan dikering-anginkan menggunakan alas dan ditutup kain hitam hingga kering dan mudah dipatahkan. Irisan rimpang kunyit kering diblender sampai menjadi serbuk halus, kemudian diambil 100 gram dan diberi $150 \mathrm{ml}$ aquabidest, lalu disaring dan diambil cairannya untuk diuapkan hingga $50 \mathrm{ml}$.

Rimpang kunyit untuk perlakuan 3, yaitu ekstrak dari proses maserasi dengan pelarut etanol $95 \%$, diambil dari serbuk halus rimpang kunyit. Proses ekstraksi dengan cara maserasi digunakan 100 gram serbuk kunyit dalam 150 gram pelarut etanol 95\%. Selama 2 jam pertama campuran terus-menerus dikocok, kemudian didiamkan selama 3×24 jam sambil sesekali dikocok. Ekstrak yang didapatkan setelah dipisahkan dari ampasnya, diuapkan dengan rotary evaporator hingga $50 \mathrm{ml}$.

Rimpang kunyit untuk perlakuan 4, yaitu ekstrak dari proses soxhletasi, digunakan 100 gram serbuk kunyit dalam $150 \mathrm{ml}$ pelarut etanol 95\%. Dilakukan proses ekstraksi dengan allihn condenser selama 2 jam pada suhu $100^{\circ} \mathrm{C}$. Hasil ekstrak diuapkan dengan rotary evaporator untuk menghilangkan etanol hingga tinggal $50 \mathrm{ml}$.

Keempat perlakuan memiliki konsentrasi rimpang kunyit yang sama, yaitu 2 gram $/ \mathrm{ml}$. Konsentrasi tersebut ditentukan atas dasar resep obat tradisional yaitu menggunakan 400 gram rimpang kunyit untuk menghasilkan 1 gelas $(200 \mathrm{ml})$ perasan kunyit (Permatasari dan Hartanti, 2011).

Daya antibakteri dari keempat perlakuan diuji dengan metode difusi sumuran menggunakan media Mueller-Hinton Agar. Metode sumuran lebih baik daripada metode difusi disk disebabkan karena pada proses sumuran terjadi proses osmolaritas. Konsentrasi ekstrak yang lebih tinggi dibandingkan dengan metode difusi disk sehingga osmolaritas terjadi secara menyeluruh dan lebih homogen dan lebih kuat untuk menghambat pertumbuhan bakteri (Arirahmayanti et.al., 2019). Prinsip kerja metode difusi adalah terdifusinya senyawa yang diuji ke dalam media padat dimana bakteri uji telah diinokulasikan. 
Hasil pengamatan yang diperoleh berupa ada atau tidaknya daerah bening yang terbentuk di sekeliling sumuran yang menunjukan zona hambat pada pertumbuhan bakteri (Nurhayati et.al., 2020). Konsentrasi uji sediaan rimpang kunyit dari 4 perlakuan masing-masing digunakan dosis sebanyak $25 \mu \mathrm{L}, 50 \mu \mathrm{L}$, dan $75 \mu \mathrm{L}$ yang setara dengan $50 \mathrm{mg}, 100 \mathrm{mg}$, dan 150 mg rimpang kunyit. Masing-masing penujian dilakukan replikasi sebanyak 4 kali dengan kontrol negatif pelarut aquabidest (Cahaya Himawan et.al., 2012). Bakteri usus yang digunakan dalam pengujian adalah Escherichia coli, Yersinia enterolitica, Vibrio nonaglutinase, dan Shigella flexneri. Jumlah bakteri yang digunakan disesuaikan dengan kekeruhan modifikasi Brown 1 yang dianggap setara dengan 300 juta bakteri per ml. Masa inkubasi 24 jam pada suhu $37^{\circ} \mathrm{C}$. Daya antibakteri diukur dengan mengukur diamter area jernih di sekitar sumuran (Cahaya Himawan et.al., 2012).

\section{HASIL DAN PEMBAHASAN}

Determinasi tanaman dilakukan atas dasar membandingkan ciri morfologi tanaman dengan pustaka sebelumnya. Tanaman kunyit yang digunakan memiliki ciri tulang daun dan urat daun sejajar, letak daun berselang-seling serupa tangga memutar, daun berbentuk lancip, memiliki pelepah yang melingkari batang, dan merupakan herba dengan rimpang, Berdasarkan ciri morfologi tersebut, maka dapat dikatakan tanaman yang digunakan adalah spesies Curcuma domestica, Val (Anshori et.al., 2014)

Tabel 1. Rata-rata Diameter Daya Hambat

\begin{tabular}{|c|c|c|c|c|c|}
\hline \multirow{2}{*}{\multicolumn{2}{|c|}{$\begin{array}{l}\text { Sediaan galenis } \\
\text { dan dosis }\end{array}$}} & \multicolumn{4}{|c|}{ mm diameter hambatan } \\
\hline & & \multirow{2}{*}{$\begin{array}{c}\begin{array}{c}\text { Escherichia } \\
\text { coli }\end{array} \\
0,0\end{array}$} & \multirow{2}{*}{$\begin{array}{c}\begin{array}{c}\text { Yersinia } \\
\text { enterolitica }\end{array} \\
0,0\end{array}$} & \multirow{2}{*}{$\begin{array}{c}\text { Vibrio } \\
\begin{array}{c}\text { nonaglutinabl } \\
e\end{array} \\
0,0\end{array}$} & \multirow{2}{*}{$\begin{array}{c}\text { Shigella } \\
\text { Flexneri }\end{array}$} \\
\hline Kontrol & & & & & \\
\hline \multirow{3}{*}{$\begin{array}{l}\text { Perasan } \\
\text { rimpang } \\
\text { segar }\end{array}$} & $25 \mu l$ & 0,0 & 0,0 & 0,0 & 0,0 \\
\hline & $50 \mu \mathrm{l}$ & 0,0 & 0,0 & 0,0 & 0,0 \\
\hline & $75 \mu l$ & 0,0 & 0,0 & 0,0 & 0,0 \\
\hline \multirow{3}{*}{$\begin{array}{l}\text { Perasan } \\
\text { rimpang } \\
\text { kering }\end{array}$} & $25 \mu l$ & 0,0 & 0,0 & 0,0 & 0,0 \\
\hline & $50 \mu \mathrm{l}$ & 0,0 & 0,0 & 0,0 & 0,0 \\
\hline & $75 \mu l$ & 0,0 & 0,0 & 0,0 & 0,0 \\
\hline \multirow{3}{*}{$\begin{array}{l}\text { Ekstrak dari } \\
\text { maserasi }\end{array}$} & $25 \mu \mathrm{l}$ & 6,3 & 6,7 & 10,2 & 7,0 \\
\hline & $50 \mu \mathrm{l}$ & 7,0 & 7,4 & 11,3 & 8,0 \\
\hline & $75 \mu \mathrm{l}$ & 7,7 & 7,8 & 12,7 & 8,3 \\
\hline \multirow{3}{*}{$\begin{array}{l}\text { Ekstrak dari } \\
\text { soxhletasi }\end{array}$} & $25 \mu \mathrm{l}$ & 7,3 & 8,2 & 10,3 & 7,8 \\
\hline & $50 \mu \mathrm{l}$ & 7,5 & 9,3 & 11,6 & 8,1 \\
\hline & $75 \mu l$ & 8,0 & 10,9 & 14,8 & 8,5 \\
\hline
\end{tabular}


Identifikasi makroskopis rimpang kunyit berbentuk bulat panjang kadang bercabang, warna daging rimpang kuning jingga di bagian luar dan kucing pucat di bagian dalam, batas korteks dan silinder pusat jelas, berbau khas aromatik, serta rasa pedas. Sedangkan identifikasi mikroskopis terlihat adanya gumpalan pati berwarna kuning yang sangat banyak, sering terlihat sel parenkim, fragmen jaringan gabus, butir pati dengan bentuk tidak beraturan, fragmen pembuluh, dan ada kelenjar minyak berwarna kuning. Identifikasi berdasarkan ciri makroskopis dan mikroskopis rimpang kunyit dibandingkan dengan pustaka dan didaptkan bahwa spesies yang digunakan adalah Curcuma domestica, Val (Trimanto et.al., 2018)

Hasil pengujian aktivitas antibakteri dari rimpang kunyit dari keempat perlakuan dapat dilihat pada tabel 1. Rimpang kunyit dengan perlakuan mengikuti cara tradisional turun-temurun, yaitu dengan cara diperas dari rimpang segar dan perasan dari rimpang kering menunjukkan aktivitas antibakteri yang sangat kecil dibandingkan dengan hasil ekstraksi baik dengan cara maserasi maupun soxhletasi.

Proses penguapan cairan dari keempat perlakuan menyebabkan menguapnya minyak atsiri dari rimpang kunyit. Penguapan cairan dari perasan rimpang segar dan kering dimaksudkan agar mendapatkan konsentrasi yang memadai untuk pengujian daya antibakteri. Sedangkan penguapan pada proses ekstraksi bertujuan untuk menghilangkan alkohol yang dapat mempengaruhi hasil uji aktivitas antibakteri, selain itu agar konsentrasi ekstrak dapat mencukupi untuk dilakukan uji daya antibakterinya

Selain minyak atsiri, rimpang kunyit mengandung senyawa metabolit sekunder terpenoid, alkaloid, flavonoid, dan kurkuminoid yang berfungsi sebagai antimikroba. Senyawa flavonoid mampu merusak dinding sel bakteri, sehingga bakteri mengalami lisis. Flavonoid juga dapat menghambat pembentukan protein sehingga menghambat pertumbuhan bakteri. Sedangkan mekanisme aksi alkaloid dalam membunuh bakteri adalah dengan cara mendenaturasi protein sehingga merusak aktivitas enzim dan menyebabkan kematian sel (Dermawaty, 2015).

Ketiadaan minyak atsiri dalam semua perlakuan menyebabkan aktivitas antibakteri yang diakibatkan oleh minyak atsiri tidak terdeteksi. Aktivitas antibakteri rimpang kunyit yang terdeteksi adalah dipengaruhi oleh adanya flavonoid, alkaloid, dan kurkuminoid dalam rimpang kunyit. Metabolit sekunder tersebut berada di dalam sel ata intraselular, yaitu di dalam vakuola. Pelarut organik dalam hal ini etanol $95 \%$ mengakibatkan terbukanya seluruh sel-sel rimpang kunyit sehingga ekstraksi ini mampu melepaskan metabolit sekunder dalam kadar yang cukup untuk meghasilkan aktivitas antibakteri. Hal inilah yang menjadi alasan dibuktikannya daya antibakteri ekstrak dari proses maserasi maupun soxhletasi.

Bakteri uji yang paling sensitif terhadap rimpang kunyit adalah bakteri Vibrio nonaglutinable. Bakteri uji ini sering ditemukan di dalam sampel tinja dari penderita diare. Vibrio nonaglutinable juga merupakan kerabat dari bakteri penyebab kolera, yaitu Vibrio cholerae yang lebih patogen dan menyebabkan kematian terbesar dari penyakit diare.

Penelitian ini tidak memperhitungkan keberadaan minyak atsiri yang terdapat dalam rimpang kunyit, padahal kemungkinan minyak atsiri ini memiliki aktivitas antibakteri yang tidak bisa diabaikan. Oleh sebab itu perlu dilakukan penelitian untuk daya antibakteri minyak atsiri dari rimpang kunyit. Bakti uji dalam 
penelitian ini terbatas pada 4 jenis bakteri, dan masih banyak berbagai jenis yang ditemukan dalam kasus diare, dengan demikian dapat dilakukan penelitian lebih lanjut untuk meneliti efek antibakteri rimpang kunyit terhadap bakteri dari genus Vibrio karena daya hambat terbesar ditunjukkan dari bakteri uji Vibrio nonaglutinable.

\section{KESIMPULAN}

Proses tradisional dalam pengolahan rimpang kunyit, yaitu perasan rkunyit segar maupun perasan kunyit yang telah dikeringkan, tidak menunjukkan efek antibakteri terhadap bakteri uji Escherichia coli, Yersinia enterolitica, Vibrio nonaglutinase, dan Shigella flexneri. Sedangkan proses ekstraksi dengan pelarut etanol $95 \%$ dengan cara maserasi ataupun soxhletasi menunjukkan aktivitas antibakteri terhadap bakteri uji. Bakteri uji yang paling sensitif terhadap maserat dan ekstrak rimpang kunyit adalah bakteri Vibrio nonaglutinable dan diikuti bakteri Yersinia enterolitica.

\section{UCAPAN TERIMA KASIH}

Penulis mengucapkan terima kasih kepada Kepala Laboratorium Kesehatan dan Kalibrasi Provinsi DIY yang telah memfasilitasi dalam pengujian daya antibakteri. Dekan Fakultas Farmasi Universitas Gadjah Mada yang telah memberikan izin penggunaan laboratorium dalam penelitian ini.

\section{DAFTAR PUSTAKA}

Anshori, Y.R., Aisyah, S.I., Darusman, L.K., 2014, Induksi Mutasi Fisik dengan Iradiasi Sinar Gamma pada Kunyit (Curcuma domestica Val.), Jurnal Hortikultura Indonesia, 5 (2): 84-94

Arirahmayanti, I.G.A.E., Artini, I.G.A., Ernawati, D.K., 2019, Perbandingan Aktivitas Antibakteri Ekstrak Etanol Kunyit (Curcuma longa) dan Bawang Putih (Allium sativum) terhadap
Escherichia coli ATCC 8739, Jurnal Medika Udayana, 8 (11): 1-5

Backer, C.A., van den Brink, Rob, 1968, Flora of Java, volume IIIA, Wolter, Noordhff N.V., Groningen, Nederland: 41-42,64-73.

Cahaya Himawan, H., Surjana, V., Prawira, L., 2012, Karakterisasi dan Identifikasi Komponen Kimia Rimpang Kunyit (Curcuma domestica Val.) Sebagail Inhibitor Bakteri Patogen, Jurnal Imiah Farmasi, 2 (2): 116-125

Dermawaty, D.A., 2015, Potential Extract Curcuma (Curcuma xanthorrizal, Roxb) as Antibacterials, Jurnal Majority, 4 (1): 5-11

Dewoto, Hedi R., 2007, Pengembangan Obat Tradisional Indonesia Menjadi Fitofarmaka, Majalah Kedokteran Indonesia, 57 (7) : 7

Irianto, J., 2000, Prediksi Keparahan Diare menurut Faktor-faktor yang Berpengaruh pada Anak Balita di Indonesia, Pusat Penelitian dan Pengembangan Ekologi dan Status Kesehatan Kemkes R.I., Jakarta

Muadifah A., Putri, A.E., Latifah, N., 2019, Aktivitas Gel Ekstrak Rimpang Kunyit (Curcuma domestica Val.) terhadap Bakteri Staphylococcus aureus, Jurnal SainHealth, 3 (1): 45-53

Nugroho, Ardiyanto W., 2017, Review: Konservasi Keanekaragaman Hayati melalui Tanaman Obat dalam Hutan di Indonesia dengan Teknologi Farmasi: Potensi dan Tantangan, Jurnal Sains dan Kesehatan, 1 (7) : 377-383

Nurhayati, L.S., Yahdiyani, N., Hidayatulloh, A., 2020, Comparion of the Antibacterial Activity of Yoghurt Starter with Disk Diffusion Agar dan Well Diffusion Agar Methods, Jurnal Teknologi Hasil Peternakan, 1 (2): 41 46

Permatasari, D. dan Hartanti D., 2011, Studi Etnofarmakologi Obat Tradisional sebagai Anti Diare di Kecamatan Baturaden Kabuaten Banyumas, Pharmaceutical Journal of Indonesia, 8 (1): 21 
Trimanto, Dwiyanti, D., Indriyani, S., 2018, Morfologi, Anatomi dan Uji Histokimia

Rimpang Curcuma aeruginosa Roxb;

Curcuma longa L.; Curcuma domestica Val. dan Curcuma

heyneana Valeton dan Zijp, Berita

Biologi, 17 (2): 123-13 